\title{
Dossiê: Ensinando a cidade: reflexões sobre o ensino das questões urbanas
}

Adriana Dorfman *

O presente número da Revista Cadernos do Aplicação reúne textos que refletem sobre experiências no ensino das questóes urbanas. $\mathrm{O}$ estudo das cidades adquire destaque devido ao fato de que mais de $80 \%$ da população brasileira reside nesses espaços, quase sempre nas regióes metropolitanas. Além disso, as principais decisões políticas e econômicas que têm repercussões na organização do território são tomadas nas metrópoles, sendo também aí que ocorrem efetivamente a produção, apropriação e circulação do valor excedente e da mais-valia (CORRÊA, 1999).

Essa vasta gama de usos da cidade leva a sua abordagem por diferentes disciplinas. A Arquitetura, a Geografia, a História, a Sociologia, o Turismo, em momentos intra ou extraclasse, mostram que a cidade concentra - além de população, poder político, redes financeiras e comerciais - muitos aspectos do imaginário contemporâneo. As múltiplas expressões aqui registradas - mapas, fotos, textos, poesia, desenho... dão conta da eloquência do espaço urbano.

Diferentes momentos na escola infantil, no ensino fundamental, médio, técnico, superior, em instituições das redes públicas e particulares ou fora da escola, convocam a cidade, como objeto geográfico e social, para o exercício de conceitos

\footnotetext{
Professora Adjunta do Depto. de Geografia do IGEO-UFRGS. Mestre em Geografia pela UFRJ. Doutora em Geografia pela UFSC. E-mail: adriana.dorfman@gmail.com
} 
e processos. Os autores aqui publicados são unânimes ao afirmar que o estudo do urbano enseja a valorização das vivências prévias dos membros da comunidade escolar, a apropriação de seus lugares através das representações sociais, as ações territorializantes discentes e docentes. $\mathrm{O}$ estudo da cidade como um exercício de construção da cidadania é uma ideia motriz nos textos que seguem. Os autores acreditam que o envolvimento com o espaço urbano e vivido seja base para a transformação das cidades em lugares que expressem o desejo dos seus moradores, contribuindo para a discussão do direito à cidade, oferecendo aos alunos aspectos científicos e conhecimentos mais aprofundados que thes permitam posicionar-se e atuar. ${ }^{1}$

Outra imagem recorrente nos textos aqui agrupados refere a ideia de percurso, rota, guia, excursão: essa prática é quase um fetiche para a Geografia, uma vez que representa o corpo a corpo com o espaço concreto, o encontro da Geografia com a geografia, a verificação in loco da materialidade dos processos. As atividades extraclasse, sempre acompanhadas de preparação e exploração subsequentes, permitem incorporar as informações recebidas ou levantadas num percurso de aprendizagem bastante amplo. As saídas de campo servem a múltiplos fins: os alunos desenvolvem habilidades como observação, descrição, percepção, análise e caracterização e podem compreender que a cidade possui diferentes processos espaciais que originam os diversos subespaços que a compõem. Além disso, as excursões são momentos muito gratificantes no cotidiano escolar. É importante frisar que tais saídas de campo não visam

\footnotetext{
Segundo a Declaração pelo Direito à Cidade como Paradigma para a Existência de Cidades Democráticas, Justas, Sustentáveis e Humanas, "todos os seres humanos, em especial as mulheres, as crianças, os jovens, os idosos, pessoas com deficiência, populações tradicionais, os moradores de áreas segregadas, migrantes e imigrantes têm direito a participar no planejamento, desenho, execução, controle, manutenção, reabilitação e melhoramento de suas cidades, povoados e vilas, com o objetivo de conquistar espaços e equipamentos adequados e com serviços de qualidade às diversas funçốes que realizam, às suas condições particulares de vida e às suas próprias aspiraçôes. $\mathrm{O}$ Direito à Cidade é o direito coletivo de todas as pessoas a uma cidade sem discriminação de gênero, idade, raça, condições de saúde, renda, nacionalidade, etnia, condição migratória, orientação política, religiosa ou sexual, assim como de preservarem sua memória e identidade cultural” (DOCUMENTO, 2010).
} 
apenas "ilustrar" os conhecimentos apresentados em sala de aula, ou exercitar a observação geográfica, mas efetivamente levantar dados e construir percepçôes informadas a respeito da cidade.

Por fim, observamos a importância na alternância entre as posiçôes de produtor, tradutor e receptor (isto é, entre as atitudes distintivas de pesquisador, professor e aluno), sempre em busca do enriquecimento das experiências cognitivas dos agentes. Nas palavras de Boaventura de Souza Santos: "E nós, quando estudamos a cidade, quando estudamos o que quer que seja, devemos sempre estar atentos a formas de conhecimento que emergem dessas comunidades [e estudantes] e que são capazes de nos surpreender com outras sabedorias, outras idéias" (2001). Como colocar os alunos numa posição de produtores de conhecimento e de ações sobre seu espaço vivido? Como despertar nos jovens cidadãos o entendimento de que a cidade pode ser mudada pela atuação dos que nela vivem? Os textos que seguem se dedicam a responder tais questões. Vale lembrar que o contexto educacional muitas vezes sobrevaloriza a produção científica e desvaloriza a capacidade dos professores de se apropriarem e construírem conhecimentos científicos em sala de aula, restando aos docentes somente a reprodução de conteúdos ou a supervisão de trabalhos previamente estabelecidos nos livros didáticos. Muitos dos textos que seguem foram elaborados numa perspectiva de apropriação e reconstrução dos conhecimentos e saberes em sala de aula, considerando todos os agentes como sujeitos ativos neste processo, com destaque para a ação dos alunos, cujos saberes prévios são fundamentais para o andamento dos trabalhos em sala de aula.

Um agradecimento especial à equipe que, entre tantas demandas, aceitou o convite para editar este caderno, emprestandonos seu discernimento e credibilidade. Declaro minha profunda admiração pela competência e entusiasmo com que as editoras deste número especial, Ligia Beatriz Goulart e Neiva Schaffer, e o editor do periódico, Tadeu Bisognin, percorrem os caminhos da educação. 


\section{Referências:}

CORRÊA, Roberto Lobato. O espaço urbano. 4 ed. São Paulo: Ática, 1999. 94p.

DOCUMENTO final do FUMt considera Declaração do Fórum Nacional de Reforma Urbana. Disponível em: http://www.direitoacidade.org/blog/ Acesso em 18 de mar. 2010.

HAESBAERT, Rogério. Des-territorialização e identidade: a rede "gaúcha" no nordeste. Niterói: EdUFF, 1997.

SANTOS, Boaventura de Souza. A territorialização/desterritorialização da exclusão/inclusão social no processo de construção de uma cultura emancipatória. São Paulo: [s/e], 2001. Disponível em http://www.cedest. info/Boaventura.pdf. Acesso em 11 de set. 2008. 